\title{
Meningkatkan Kompetensi Pendidik di Era Pembelajaran Abad 21 dengan Menjadi Guru Blogger
}

\author{
Nurmida Catherine Sitompul ${ }^{1}$, Rufi'i ${ }^{2}$, Ibut Priono Leksono ${ }^{3}$, Heri Wahyu Rejeki ${ }^{4}$ \\ Universitas PGRI Adi Buana Surabaya ${ }^{1,2,3}$, SMP Negeri 3 Taman Sidoarjo ${ }^{4}$ \\ nurmida.catherine.s@unipasby.ac.id ${ }^{1}$,rufii@unipasby.ac.id ${ }^{2}$, ibutpriono@unipasby.ac.id ${ }^{3}$ \\ heriwahyu53@gmail.com ${ }^{4}$
}

\begin{abstract}
Learning in 21st centuries should have 4 C's skill. The 4 C's skill are creative, collaboration, critical thinking and communication. All these skills is needed to make students a problem solver. Teaching the $4 \mathrm{C}$ 's skill in the classroom requires variaties of instructional materials, contextual informations riil datas, severals formats of data (word, spreadsheed, ppt, video, animation) and should be easy to acces in short time. All these kind of infomation will be used of the students to analyses to solve the problems from many point of views. Blog is one of digital application can be provided informations/datas in teaching 4 C's Skill. Fortunatelly almost all schools ini city have already have computers and internets facilitation, but still do not use yet for learning. The purpose of this activity is to train teachers to create their own Blog to facilitate student's learning. The result showed that all teachers can create a Blog for their Subject.
\end{abstract}

Keywords: Blog; Online Learning; Problem Based Learning; The 4 C's skill

\begin{abstract}
Abstrak
Pembelajaran abad 21 memerlukan 4 keterampilan yang dinamakan dengan 4 C's Skill, yaitu kreatifitas, kolaborasi, berpikir kritis dan komunikasi. Keterampilan ini diperlukan untuk mendidik siswa agar dapat menyelesaikan masalah. Pembelajaran Keterampilan $4 \mathrm{C}^{\text {'s }} \mathrm{s}$ mensyaratkan ketersediaan bahan ajar yang beragam, informasi yang kontekstual, rill, dan berbagai format data (teks, angka, ppt, animasi, video) yang dapat diakses dengan mudah dan cepat. Karakteristik bahan ajar ini diperlukan siswa dalam melakukan analisis dari berbagai sudah pandang yang berbeda untuk penyelesaian masalah. Blog adalah salah satu aplikasi digital yang dapat menyediakan informasi/data dalam pembelajaran Keterampilan 4C's. Selain itu infrastruktur yang dibutuhkan seperti fasilitas komputer dan jaringan internet telah tersedia di sekolah-sekolah di perkotaan, namun belum dimanfaatkan untuk aktivitas pembelajaran. Kegiatan Pengabdian ini telah berhasil melatih para guru mendesain Blog untuk mata pelajaran masing-masing.
\end{abstract}

Kata Kunci: Blog; pembelajaran berbasis online; Pembelajaran Berbasis Masalah; The 4 C's Skill 


\section{A. PENDAHULUAN}

Era Abad 21 atau yang dikenal dengan Revolusi Industri 4.0 terjadi sebagai dampak transformasi dari temuan teknologiteknologi baru dan penyediaan data. (World Economic Forum, 2018). Digitalisasi, otomatisasi diberbagai aktivitas manusia telah merubah cara hidup manusia secara global. Perubahan-perubahan ini terjadi sangat cepat dan tidak terduga. Kondisi ini mengubah cara hidup manusia dan menuntut keterampilan-keterampilan baru untuk sanggup menyelesaian permasalahpermasalah sebagai akibat dari perubahan yang sangat cepat dan tidak terduga. Bidang pendidikan menghadapi tantangan menghadapi perubahan ini karena harus memformulasikan kembali tujuan-tujuan pembelajaran di sekolah. Cara-cara belajar selama ini dengan seperangkat tujuan yang ada tidak bisa dipertahankan lagi karena tidak sesuai dengan keterampilanketerampilan yang dibutuhkan untuk hidup di Revolusi Industri. Laporan The Future of Jobs Report 2018 dikeluarkan oleh World Economic Forum (2018) menguraikan analisis pekerjaan di masa depan yang menuntut bidang pendidikan untuk mempersiapkan peserta didik dengan kompetensi yang sesuai dengan perkembangan jaman. Abad 21 yang dicirikan perubahan-perubahan yang begitu cepat sehingga menimbulkan permasalahan baru menuntut cara-cara baru dalam pemecahannya. Kondisi ini menuntut sumberdaya manusia yang memiliki keterampilan untuk mengidentifikasi masalah dan menyelesaikan masalah atau problem solver.

Pembelajaran pemecahan masalah ini akan mengembangkan 4 keterampilan utama yaitu kreatifitas, kolaborasi, berpikir kritis dan komunikasi (Lai, Yarbro, DiCerbo, and de Geest, 2018) atau disingkat 4 Cs Skill yang merupakan singkatan dari Creativity, Collaboration, Critical Thinking dan Communication. Pendidikan saat ini harus lebih diarahkan pada kemampuan untuk pemecahan masalah sebagai akibat dari terjadinya perubahan-perubahan yang begitu cepat dan tidak terduga.

Kementerian Pendidikan dan Kebudayaan (2014) menyadari hal ini dan menanggapinya melalui pengembangan kurikulum. Salah satu kebijakan Kemdikbud melalui Kurikulum 2013 adalah pembelajaran di sekolah secara nasional menerapkan metode-metode berbasis masalah yang terdiri atas Pembelajaran berbasis masalah (Problem Based Learning), penemuan (Inquiry Learning) dan proyek (Project Based Learning). Ketiga metode ini adalah metode untuk meningkatkan keterampilan berpikir (Hanipah, Florentius, dan Rifai, 2018). Metode-metode berisikan langkah-langkah yang bertujuan untuk mengembangkan keterampilan memecahkan masalah.

Belajar pemecahan masalah (PBL) memerlukan seperangkat informasi atau data yang bersifat rill karena dalam PBL para siswa diperhadapkan pada konteks tertentu, masalah-masalah yang tak terstruktur, dimana para peserta didik dilatih untuk mendefinisikan masalah dan menemukan cara penyelesaiannya (David, 2014). Pembelajaran PBL mensyaratkan ketersediaan informasi atau data dari berbagai sumber, kontekstual, riil, dan up to date. Kemajuan Information and Communications Technology (ICT) memampukan penyediaan data atau informasi untuk pembelajaran PBL. Pemanfaatan ICT di sekolah-sekolah, 
khususnya di Surabaya dan Sidoarjo sudah dilakukan karena hampir semua sekolah telah memiliki laman website sekolah, namun belum dimanfaatkan untuk pembelajaran. Bila PBL sungguh-sungguh di implementasikan di sekolah maka seharusnya mendorong setiap sekolah menggunakan fasilitas ICT yang ada terintegrasi dengan proses pembelajaran. Tetapi hasil temuan searching TIM PPM (Sitompul, Rufi'i dan Leksono, 2019) menunjukkan tidak ada pemanfaatan website sekolah di kedua kawasan tersebut untuk pembelajaran. Kondisi ini salah satu motivasi pelaksanaan pengabdian ini. Padahal sebagian sekolah telah memiliki fasilitas internet dan laboratorium komputer. Website sekolah lebih bersifat administratif atau berita tentang kegiatan sekolah. Fasilitas komputer banyak dimanfaatkan untuk penyelenggaraan ujian berbasis komputer misalnya UNBK yang dilakukan setiap tahun.

Blog dipilih sebagai aplikasi ICT dengan pertimbangan bahwa aplikasi ini cukup mudah untuk dipelajari dan telah banyak dimiliki perorangan bahkan lembaga. Lembaga yang telah memanfaatkan Blog untuk sarana menyebarkan informasi, misalnya Pusat Ilmu Pengetahuan dan Teknologi atau Puspiptek (2018) salah satu lembaga di bawah naungan Kementerian Riset, Teknologi, Dan Pendidikan Tinggi Republik Indonesia yang pada tahun 2018 menggelar Writingthon yaitu kompetisi menulis populer mengenai Puspiptek dan karyakarya yang dihasilkan di kawasan tersebut. Writingthon \#2 ini mengundang sejumlah Blogger terpilih untuk membantu mensosialisasikan teknologi yang dimiliki Indonesia kepada masyarakat. Selain itu lembaga setingkat regional Asia Tenggara yaitu SEAMEO SEAMOLEC (https://seamolec.org/) juga menggalakkan pelatihan Blog sebagai sarana pembalajaran yang dapat langsung dimanfaatkan untuk pembelajaran.

Blog memiliki sejumlah kemampuan untuk menampilkan informasi atau data dalam berbagai format digital. Format digital tersedia di dunia maya dalam jumlah yang sangat banyak (mungkin tidak terbatas), beragam, berbagai format dan up to date. Format digital berbentuk words, spreadsheet, pdf, ppt, film, animasi dan sebagainya, masing-masing memiliki kemampuan khusus untuk memberikan pengalaman belajar. Sumber belajar ini diharapkan dapat memfasilitasi para peserta didik untuk memahami konsep-konsep pembelajaran dari berbagai sudut pandang untuk pemahaman yang lebih lengkap (Carr, 2018).

Salah satu sekolah yang sangat potensi mengembangkan Blog adalah adalah SMP Negeri Taman Sidoarjo (https://www.smpn3taman.sch.id). Sekolah ini merupakan sekolah model yang memiliki fasilitas 3 Laboratorium Komputer berkapasitas 110 komputer. Terdapat juga jaringan internet/hot spot yang cukup di seluruh sekolah. Sekolah ini juga memiliki 1 orang guru IT dengan kompetensi yang baik. Adanya sumberdaya manusia dan sarana prasarana yang belum dimanfaatkan untuk pembelajaran ini mendorong Prodi Magister Teknologi Pendidikan UNIPA Surabaya memberikan layanan pelatihan Blog agar meningkatan kompetensi guru untuk menggunakan ICT. Aplikasi Blog dipilih karena lebih sederhana untuk dipelajari namun banyak fitur yang dapat dimanfaatkan sebagai sumber belajar sehingga para guru dapat mendesain Blog 
pembelajarannya sesuai dengan karakteristik siswa dan tujuan pembelajaran dari mata pelajaran mereka masing-masing.

Gambar 1 menunjukkan website sekolah SMP Negeri 3 Taman Sidoarjo. Terlihat konten bagian beranda adalah informasi, jadual dan berbagai kegiatan yang dilakukan sekolah. Terdapat menu Blog Guru di sudut kanan atas, sebagai hasil dari kegiatan pengabdian ini. Sebelum pelatihan, menu tersebut tidak ada.

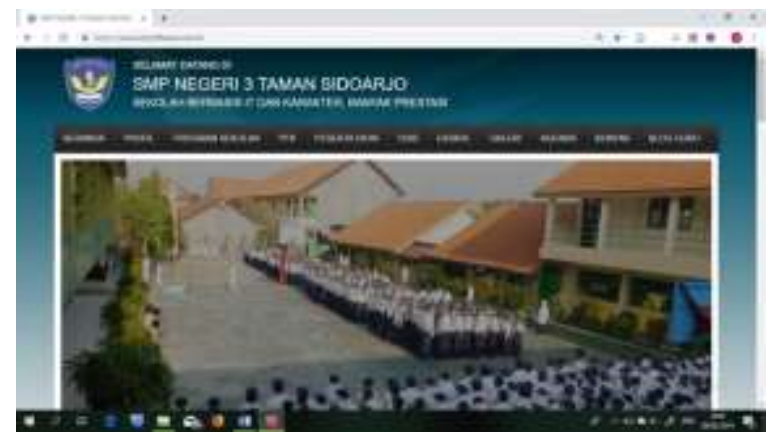

Gambar 1. Website SMPN 3 Taman Sidoarjo (sumber: https://www.smpn3taman.sch.id/)

Prodi Magister TEP bersama kepada sekolah merancang pelatihan Blog yang bertujuan untuk meningkatkan kompetensi guru pada bidang ICT sehingga guru dapat mendesain blog sendiri sesuai dengan karakteristik mata pelajaran dan karakteristik siswa dan sekolah. Luaran yang diharapkan dari kegiatan pengabdian ini adalah: 1) para guru mendapatkan landasan teoritik dan praktis tentang pembelajaran online secara umum dan pembelajaran Blog secara khusus; 2) para guru dapat mendesain Blog untuk mata pelajaran yang diampu, 3) Website SMPN 3 Taman telah menyediakan menu Blog Guru yang dapat diakses para siswa untuk peningkatkan proses pembelajaran dan sarana belajar bagi masyakarat umum.

\section{B. PELAKSANAAN DAN METODE}

Kegiatan pengabdian dirancang sejak bulan Oktober 2018 dan pelaksanaannya dilakukan pada bulan Januari sampai akhir bulan Februari 2019. Perancangan dilakukan dengan kepala sekolah SMPN 3 Taman (sekaligus mahasiswa S2 Teknologi Pembelajaran UNIPA Surabaya) untuk mendapatkan informasi kondisi guru, fasilitas sekolah dan penetapan jadual pelatihan di kampus UNIPA Surabaya dan pendampingan di sekolah. Kegiatan pelatihan dilaksanakan pada tanggal 19 Januari 2019 bertempat di Kampus UNIPA Surabaya pada pukul 08.00-17.00 wib. Kegiatan dilanjutkan dengan pendampingan di sekolah SMP Negeri 3 Taman, Sidoarjo sebanyak 2 kali pertemuan pada tanggal 23 dan 31 Januari 2019. Kegiatan diikuti oleh 39 orang guru. Meski ada 5 peserta yang pernah membuat Blog namun secara umum seluruh guru belum pernah membuat Blog secara mandiri kecuali guru IT. Kondisi latar belakang para guru ini memerlukan pelatihan dengan langkah-langkah menyesuaikan dengan kecepatan belajar para guru dan pengetahuan awal tentang format-format digital dan online. Kegiatan pelatihan dimanfaatkan dengan penandatanganan Memorandum of Agreement (MoA) untuk keberlanjutan kerjasama. Penutupan kegiatan dilakukan di sekolah yang diisi dengan presentasi Blog para guru yang telah di unduh di laman website sekolah.

Metode yang digunakan dalam kegiatan pengabdian ini ada 2 yaitu a) pelatihan dan b) pendampingan. Pelaksanaan kegiatan dilakukan sebagai berikut:

1. Pelatihan guru yang terdiri atas 2 kegiatan utama yaitu pemaparan materi tentang landasan teoritik dan praktis pembelajaran online dan kegiatan 
pelatihan teknis perancangan Blog. Materi yang didiskusikan yaitu a) Perkembangan Abad 21 dan Dampaknya pada Pembelajaran di Sekolah, b) Pembelajaran pada Era Revolusi 4.0 dan c) Strategi Pembelajaran Era Big Data: Pemanfaatan Blog. Materi ini berlangsung sekitar 2 jam. Gambar 2 menampilkan sesi materi yang ke 3 .

Bagian kedua adalah pelatihan teknik mendesain Blog yang dipimpin kepala Laboratorium Produksi Media.

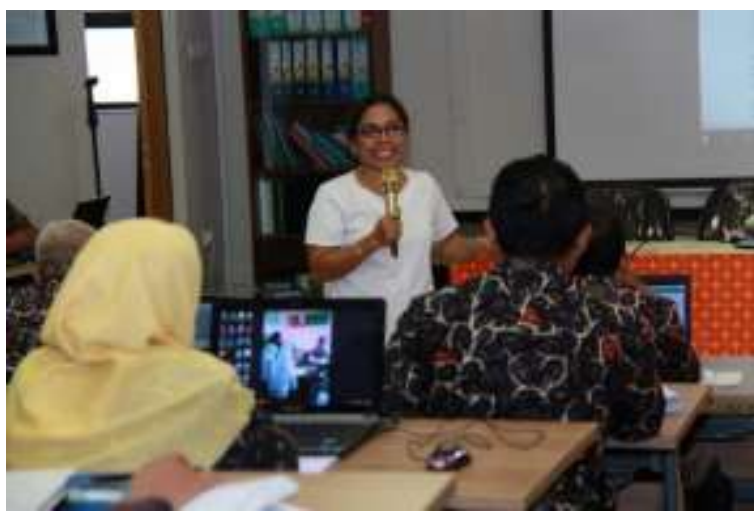

Gambar 2. Sesi Strategi Pembelajaran Era Big Data: Pemanfaatan Blog

Langkah demi langkah teknik mendisain Blog yaitu mulai dari membuat akun email, akun Blog, mendesain awal Blog, memperkenalkan berbagai format digital, (words, spreadsheet, pdf, ppt, film, animasi dan sebagainya), cara menginsert ke dalam Blog dan berbagai hal-hal teknis yang cukup rinci yang harus dikenali kegunaannya dan cara kerjanya. Gambar 3 menunjukkan aktivitas pelatih membimbing para guru.

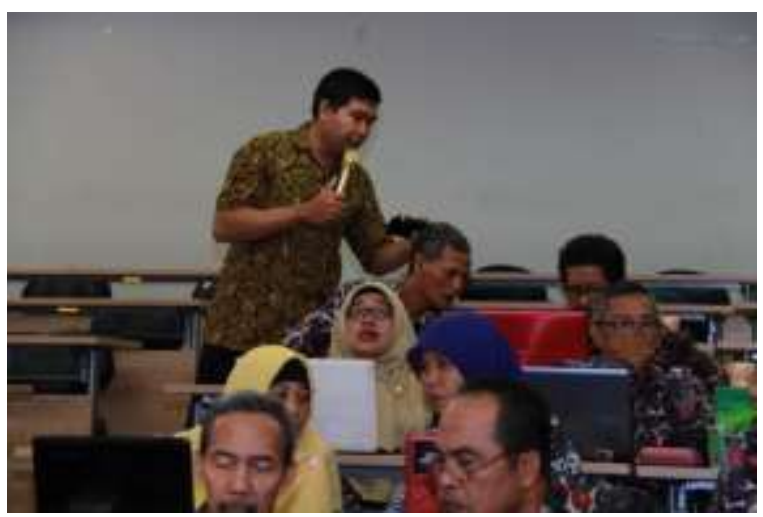

Gambar 3. Pelatihan teknis mendesain BLOG

2. Pendampingan guru di sekolah adalah metode yang kedua. Kegiatan ini dilakukan di sekolah dan pada hari sekolah. Para guru didampingi menyelesaikan desain Blog yang telah dikerjakan sebelumnya di kampus UNIPA Surabaya. Aktivitas dilakukan di ruang guru sehingga sangat memudahkan para guru untuk tetap mengikuti kegiatan pendampingan dan sekaligus tetap melaksanakan tugas di sekolah yang tidak bisa ditinggalkan. Para guru didampingi sampai bisa diunggah Blog di laman website sekolah. Kegiatan ini dilakukan sebanyak 2 kali. Pelatih juga membentuk wa grup untuk para guru konsultasi.

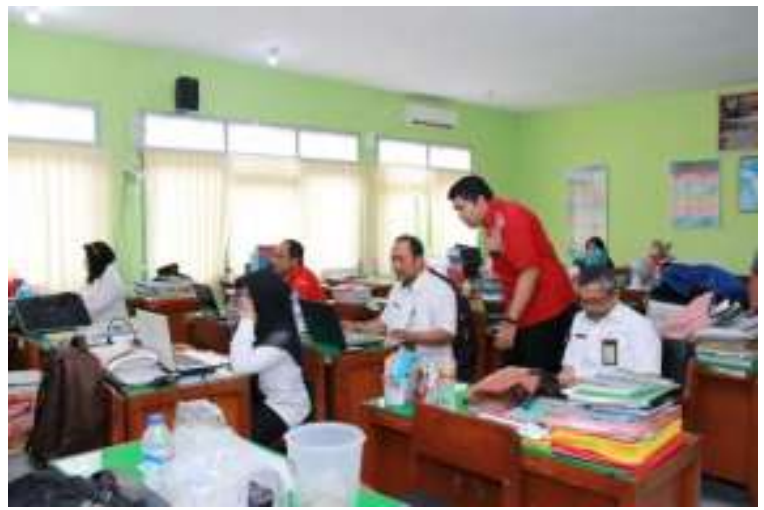

Gambar 4. Pendampingan di sekolah 


\section{C.HASIL DAN PEMBAHASAN}

Kegiatan pelatihan dan pendampingan ini menghasilkan produk pembelajaran sebanyak 39 Blog. Gambar 5 adalah daftar 39 alamat Blog para guru yang dapat di akses di https://www.smpn3taman.sch.id/blog-guru/

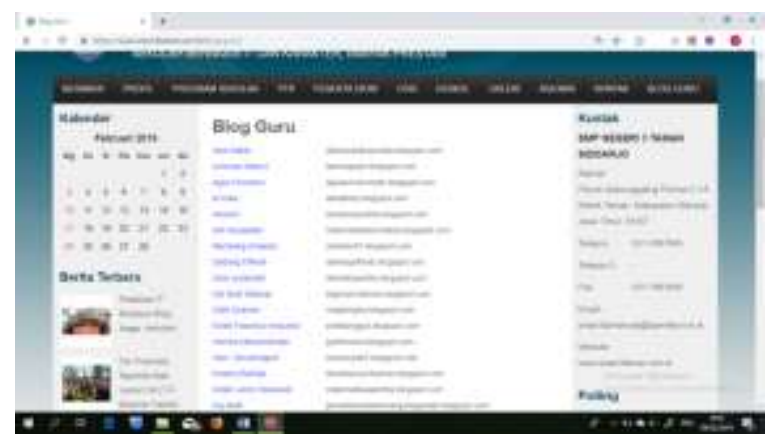

Gambar 5. Daftar alamat BLOG guru (sumber: https://www.smpn3taman.sch.id/blog-guru/

Berikut ini adalah beberapa BLOG karya guru sesuai dengan mata pelajaran yang diampu.

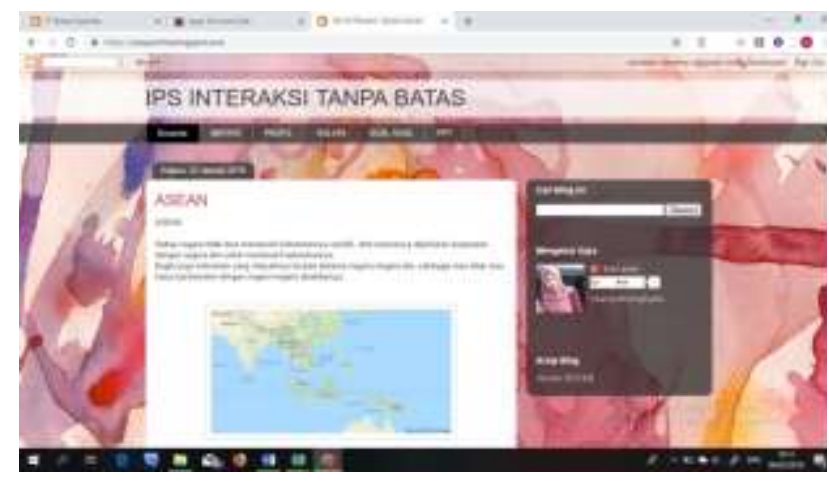

Gambar 6. Blog mata pelajaran IPS

Gambar 6 adalah BLOG guru mata pelajaran IPS. Guru mendesain Blog yang terdiri atas 6 menu yaitu: beranda, materi, profil, soalsoal, galeri, dan ppt. Bahan ajar yang berhasil dirancang tentang ASEAN. Materi tentang ASEAN dilengkapi dengan peta dan juga ada berita tentang kegiatan ASEAN yang di sadur dari berita online dan menu untuk soal-soal. Guru telah menyediakan menu 'ppt', yang dipersiapkan untuk memasukkan bahan-bahan presentasi baik yang dapat dibuat sendiri atau di unduh dari sumber-sumber online.

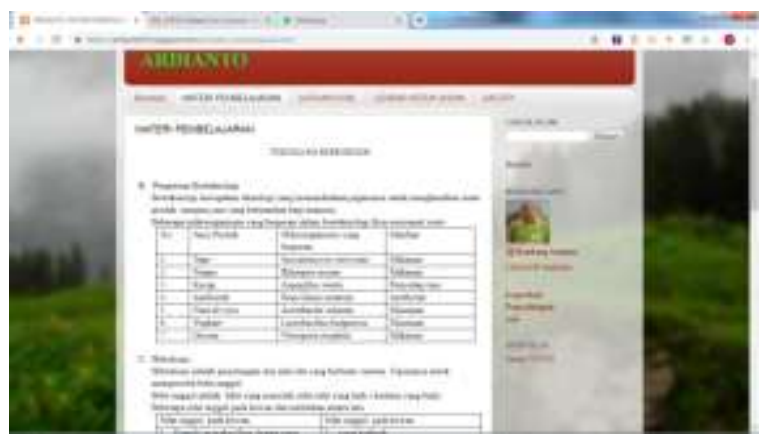

Gambar 7. Blog mata pelajaran IPA

Gambar 7 merupakan Blog guru mata pelajaran IPA. Guru mendesain Blog dalam 5 menu yaitu beranda, materi pembelajaran latihan soal, lembar kerja siswa dan galeri. Tema yang ditampilkan adalah tentang Bioteknologi. Bahan ajar di sediakan di menu materi pembelajaran, dilanjutkan bahan untuk aktifitas siswa yang harus dikerjakan di menu lembar kerja siswa dan menu terakhir adalah latihan soal.

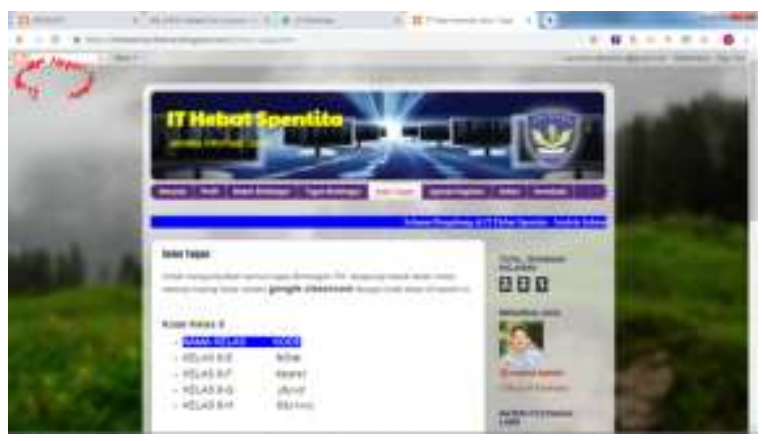

Gambar 8. Blog mata pelajaran IT

Contoh Blog guru selanjutnya adalah yang dirancang guru IT. Guru merancang 7 menu yaitu Beranda, Profil, Materi Bimbingan, Setor Tugas, Agenda Kegiatan, Galeri, dan 
Download. Terlihat guru IT telah mengintegrasikan Blog untuk kegiatan pembelajaran dimana bahan ajar, tugas dan pengumpulan tugas harus dilakukan siswa secara online dengan memanfaatkan aplikasi Google Classroom.

Secara umum semua guru telah berhasil membuat Blog sendiri, namun dengan kualitas yang berbeda. Guru mata pelajaran IT telah menggunakan berbagai format data dan mengintegrasikan dengan aplikasi yang lain yang tidak diajarkan pada saat pengabdian ini (Google Classroom). Guru juga mengintegrasikan Blog dalam proses pembelajaran dengan bahan ajar, soal latihan, penyerahan tugas harus dilakukan siswa secara online. Guru mata pejaran IPS memaparkan informasi yang dilengkapi dengan peta dan juga menyediakan berita online di tentang ASEAN, sehingga konteks peran ASEAN semakin dipahami oleh para siswa. Sedangkan guru mata pelajaran IPA masih banyak menggunakan format teks namun menu-menu yang dirancang sudah saling mendukung pemahaman para siswa terhadap materi pelajaran.

Beberapa Blog yang telah dirancang guru masih dalam penyediaan Menu Blog saja tapi belum lengkap dengan konten yang layak. Kemampuan merancang Blog ini sangat ditentukan oleh pengetahuan awal para guru tentang berbagai format digital dan juga kebiasaan menggunakan media digital dan online.

Capaian dari kegiatan pengabdian ini dapat diuraikan sebagai berikut: 1) Setiap Guru telah berhasil mendesain Blog pembelajaran untuk mata pelajaran yang diampu. Kualitas blog beragam mulai dari sangat lengkap sampai kepada sangat sederhana. Kualitas yang sangat lengkap adalah Blog yang telah menggunakan berbagai format data, menggabungkan dengan aplikasi yang lain dan telah diintegrasikan dalam proses pembelajaran (bahan ajar, tugas dan pengumpulan tugas menggunakan fasilitas Blog). Kualitas yang sangat sederhana adalah Blog dengan tampilan menu-menu tetapi belum/sedikit diisi dengan konten, dan 2) Tersedianya menu Blog Guru di website SMP Negeri 3 Taman yang dapat dimanfaatkan oleh para siswa dan masyarakat umum.

Beberapa faktor pendukung untuk keberhasilan Blog di sekolah ini antara lain: 1) Tersedia fasilitas komputer dan jaringan internet yang sangat memadai untuk pembelajaran berbasis online learning.

2) Guru IT dengan kompensi yang baik.

Kedua faktor pendukung ini sudah cukup untuk mengembangkan pembelajaran berbasis Blog di sekolah. Namun sangat dibutuhkan dukungan manajerial dari kepala sekolah untuk merancang dan mengembangkan pembelajaran berbasis online ini. Blog guru tidak hanya dibuat tapi juga perlu didesain dan diintegrasikan dalam pembelajaran dan harus di perbaharui secara berkala, dimana tanpa ada kebijakan dan dukungan dari aspek manajerial kepala sekolah maka konten Blog akan segera usang.

\section{PENUTUP}

\section{Simpulan}

Sekolah perkotaan secara umum telah dilengkapi dengan sarana ICT yang memadai namun belum dimanfaatkan untuk pembelajaran. SMP Negeri 3 Taman Sidoarjo memiliki fasilitas Laboratorium Komputer, jaringan internet yang cukup dan kompetensi guru IT yang baik merupakan modal kuat untuk merancang dan 
mengintegrasikan pembelajaran berbasis online learning. Menjadi Guru Blogger adalah salah satu kompetensi pendidik di Era abad 21 yang harus semakin ditingkatkan. Kegiatan pengabdian ini membuktikan para guru sanggup meningkatkan kompetensinya bila mendapat pelatihan dan pendampingan yang sesuai dengan kecepatan belajar dan disesuaikan dengan aktifitas dan tugas di sekolah. Kegiatan ini harus dilanjutkan untuk pembaharuan informasi di Blog dan dilaksanakan secara berkala.

\section{Saran}

Sekolah telah memiliki sumberdaya manusia dan sarana yang cukup untuk melaksanakan pembelajaran online, dan dimulai dengan BLOG.. Langkah yang selanjutnya yang sangat penting adalah merancang pembelajaran dalam skema sekolah sehingga ICT terintegrasi dalam proses pembelajaran. Sekolah dapat melakukannya melalui kerjasama dengan instutusi perguruan tinggi.

\section{Tindaklanjut Pengabdian}

Pengabdian ini telah memampukan guru dalam penggunaan ICT, yaitu membuat BLOG pembelajaran. Blog yang dihasilkan dengan kualitas yang beragam dan belum didisain untukk diintergrasikan ke dalam proses pembelajaran. Tindak lanjut adalah pelatihan lanjutan dengan mendesain Blog terintegrasi dalam pembelajaran.

\section{Ucapan Terima Kasih}

Ucapan terima kasih disampaikan kepada Lembaga Penelitian dan Pengambdian kepada Masyarakat Universitas PGRI Adi Buana dan SMP Negeri Taman Sidoarjo, Jawa Timur yang telah berkolaborasi mendukung fasilitas dan pendanaan kegiatan ini.

\section{E. DAFTAR PUSTAKA}

Carr, Jenni. 2018. Eploring the implication of era big data' for learning and teaching. Availabel from: URL: https://www.heacademy.ac.uk/explori ng-implications-\%E2\%80\%98-erabig-data\%E2\%80\%99-learning-andteaching

David L. Problem Based Learning. 2014. Available from: URL: https://www.learningtheories.com/problem-based-learningpbl.html

Hanipah, S., Florentius T.S, dan Rifai RC.,A., 2018. The Effectiveness of Problem Based Learning and Project Based Learning Model to Improve Natural Science Study Outcomes. Innovation Journal of Curriculum and Educational Technology Vol.7 (1), p 1-6. Available from: URL:

https://journal.unnes.ac.id/sju/index.ph p/ujet/article/view/24383

Konsep dan Implentasi Kurikulum 2013: Paparan Wakil Menteri Pendidikan dan Kebudayaan R.I Bidang Pendidikan, 14 Januari 2014. [118 screeens]. Availabel from: URL: https://www.kemdikbud.go.id/kemdik bud/dokumen/Paparan/Paparan\%20W amendik.pdf

Lai, E. R., Yarbro, J., DiCerbo, K.., de Geest, E. 2018. Skills for Today: What We Know about Teaching ans Assessing Creativity. London: Pearson Published. 5.

Pusat Penelitian Ilmu Pengetahuan dan Teknologi (PUSPIPTEK RISTEKDIKTI). 2018. Sosialisasikan Teknologi, Puspiptek 
Rangkul Blogger. Available from: URL:

http://puspiptek.ristekdikti.go.id/

Sitompul, N.C., Rufi'i, dan Leksono, I.P. 2019. Pelatihan Perancangan Blog untuk meningkatkan Kompetensi Guru di Era Pembelajaran Abad 21 di SMP Negeri 3 Taman Sidoarjo. Laporan Program Pengabdian Kepada Masyarakat. Lembaga Penelitian dan Pengabdian Kepada Masyarakat UNIPA Adi Buana. Tidak dipublikasikan.

SMP Negeri 3 Taman, Sidoarjo. Available from: URL: https://www.smpn3taman.sch.id

Southeast Asian Minister of Education Organization. Regional Online Learning Centre. (SEAMEOSEAMOLEC). Availabel from: URL: https://seamolec.org/

World Economic Forum. 2018. The Future of Jobs Report 2018. Available from: URL:

https://www.weforum.org/reports/thefuture-of-jobs-report-2018 